\title{
Evaluation of carbon dioxide released by bread dough during proving stage
}

\author{
Adriana Istudor ${ }^{1, *}$, Gheorghe Voicu ${ }^{1}$, Gheorghe Muscalu ${ }^{2}$ and Paula Tudor ${ }^{3}$ \\ ${ }^{1}$ Politehnica University of Bucharest, Faculty of Biotechnical Systems Engineering, 313 Splaiul \\ Independentei, 060042, Bucharest, Romania \\ ${ }^{2}$ Bio Tehnologi Creativ, Sos. Dudesti-Pantelimon nr 42, Bucuresti, Romania \\ ${ }^{3}$ Politehnica University of Bucharest, Faculty of Entrepreneurship, Business Engineering and \\ Management, 313 Splaiul Independentei, 060042, Bucharest, Romania
}

\begin{abstract}
This study presents the analysis of multiple bread dough proving processes with the purpose of establishing a correlation between the concentration of released carbon dioxide during fermentation and the working parameters (time and temperature). The testing was performed using a standard recipe for white bread dough, a small capacity prover with air conditioning unit for temperature and relative humidity regulation, $\mathrm{CO}_{2}$ and temperature sensors with data acquisition plate. In the first part are presented the results for 11 measurements of $\mathrm{CO}_{2}$ concentration for one dough piece fermentation process at varying proving temperatures. In the second part of the paper are presented the results of 4 measurements of $\mathrm{CO}_{2}$ for 9 dough pieces proving at temperatures between 30 and $39{ }^{\circ} \mathrm{C}$, at $3^{\circ} \mathrm{C}$ intervals. The obtained measurements of $\mathrm{CO}_{2}$ were correlated with the volume and dimensions of the finished products. The obtained results are considered relevant for this study and for the possibility of fermentation level evaluation using the quantity of $\mathrm{CO}_{2}$ released during proving. The presented study is part of an extensive research performed for the identification of a method for automated control of working regime in industrial bread dough provers using the measurements of released $\mathrm{CO}_{2}$.
\end{abstract}

\section{Introduction}

Bread making has a very important place in the food manufacturing sector and is in full process of expansion and automation. The proving process of bread dough is the largest stage of the technological process. It starts from kneading and continues during all the other operations and the first part of baking, but the final proving determines the structure of the bread, $[1,2]$ and its overall quality. The proving process takes place in enclosed spaces called provers, [3], which are usually air-conditioned. The purpose of proofing is to allow

\footnotetext{
*Corresponding author: istudor.adriana@mgbiotech.ro
} 
the expansion of the gas cells present in dough, by accumulation of carbon dioxide produced by yeast. In dough, carbon dioxide can be found as gas trapped inside the cells and dissolved in the aqueous phase, $[4,5]$. Acting as a sensitive foam structure carbon dioxide trapped in dough is difficult to determine. Evaluation of gas quantity produced during fermentation is frequently performed using volumetric methods, such as pressure variation [6-10]. In this study, was evaluated the influence of different temperatures on the carbon dioxide production during final fermentation of dough. This experimental research wishes to determine the possibility of correlating the quantity of carbon dioxide released during dough proving with the expansion level of dough in a given time and controlled conditions.

\section{Equipment and method}

During the experiments, a convection oven with proving cabinet was used. The oven is Miwe Aeromat, with 10 trays of $400 \times 600 \mathrm{~mm}$ capacity and has an integrated command panel for temperature and humidity control during baking and proving. The measurements for $\mathrm{CO}_{2}(\mathrm{ppm})$ were performed using a measuring and data acquisition device (Trotec $\mathrm{CO}_{2}$ BZ25) which offers the possibility of downloading the data on a computer using a dedicated software. The temperature and working humidity were further monitored using a metrological verified thermos hygrometer. The equipment used is presented in figure 1.

The standard bread recipe used in the experiments had in its composition the following ingredients and percentages reported to flour: white flour, FA, 0.65 extraction, water $(53 \%)$, salt $(1.8 \%)$ and compact yeast $(3 \%)$. The physio-chemical characteristics of the used flour are presented in table 1.

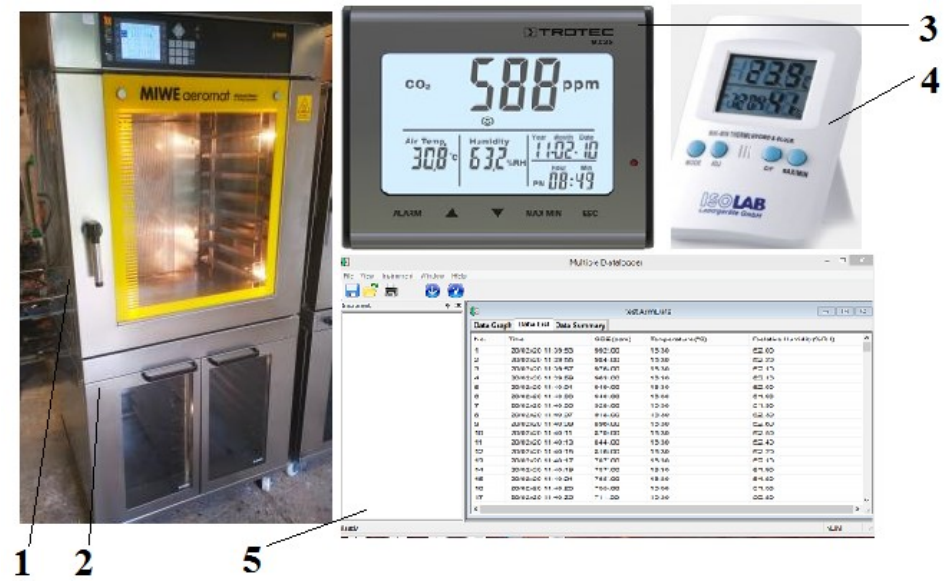

Fig. 1. The equipment used during the experiments: 1 . convection oven; 2. proving cabinet; $3 . \mathrm{CO}_{2}$ measuring device; 4 . Thermos hygrometer; $5 . \mathrm{CO}_{2}$ data software

Dough pieces with $29^{\circ} \mathrm{C}$ were divided in $360 \mathrm{~g}$ pieces each, round shaped and after 10 minutes were shaped in long cylindrical form, at $24 \mathrm{~cm}, 4.5 \mathrm{~cm}$ width and $4 \mathrm{~cm}$ height. Each proving experiment was performed for 3600 seconds at controlled temperature, in which time the $\mathrm{CO}_{2}$ device registered the concentration of released carbon dioxide in the proving chamber. 
At first, the concentration of carbon dioxide in the environment was measured (without load). At each experiment, the measurement of carbon dioxide started at $586 \mathrm{ppm}$ point value.

Table 1. The physio-chemical characteristics of the used flour

\begin{tabular}{|l|l|l|l|l|l|l|}
\hline Flour & $\begin{array}{l}\text { Humidity } \\
(\%)\end{array}$ & $\begin{array}{l}\text { Protein } \\
(\%)\end{array}$ & $\begin{array}{l}\text { Ash } \\
(\%)\end{array}$ & $\begin{array}{l}\text { Falling } \\
\text { Number } \\
(\mathrm{s})\end{array}$ & $\begin{array}{l}\text { Wet } \\
\text { gluten } \\
(\%)\end{array}$ & $\begin{array}{l}\text { Acidity } \\
\left({ }^{\circ} \text { Turner }\right)\end{array}$ \\
\hline FA & 13,5 & 10,2 & 0,65 & 308 & 27 & 1.8 \\
\hline
\end{tabular}

In the first part of the paper, measurements of released carbon dioxide were taken for one dough piece fermented at temperatures between $30{ }^{\circ} \mathrm{C}$ and $40{ }^{\circ} \mathrm{C}$, at $1{ }^{\circ} \mathrm{C}$ interval. Based on the results obtained in the first part, the working temperatures for the second part of the paper were established. The concentration of released carbon dioxide was measured for 9 dough pieces of $360 \mathrm{~g}$ each at proving temperatures between $30{ }^{\circ} \mathrm{C}$ and $39{ }^{\circ} \mathrm{C}$, at $3{ }^{\circ} \mathrm{C}$ intervals. The number of dough pieces was established taking into consideration the tray dimensions in which 3 dough pieces were placed and the proving volume necessary for optimal dough development considering the total proving volume of $0.36 \mathrm{~m}^{3}$.

In order to establish the fermentation level in correlation with the registered $\mathrm{CO}_{2}$ quantity and the working temperature, dough dimensions were measured (length, width, height) after each experiment. The optimal fermentation level was determined using the standard dimensions presented in STAS 91/1983 for white bread of 300g weight whose optimal dimensions are: length $28-30 \mathrm{~cm}$, width $10-11 \mathrm{~cm}$, height $7-8 \mathrm{~cm}$.

\section{Results and discussion}

The results obtained in the first part of the study, where 11 measurements of $\mathrm{CO}_{2}$ concentration were performed for one dough piece in $3600 \mathrm{~s}$ fermentation process at temperatures between $30{ }^{\circ} \mathrm{C}$ and $40^{\circ} \mathrm{C}$ are presented in figure 2. The purpose of these determinations was to evaluate if $1^{\circ} \mathrm{C}$ in the proving chamber has a significant influence on the fermentation level of dough and also to establish the optimal temperature interval at which the $\mathrm{CO}_{2}$ release register modifications.

Analysing the graphics in figure 2 , it can be observed that for the $30-33{ }^{\circ} \mathrm{C}$ interval the $\mathrm{CO}_{2}$ development curves are linear and the $\mathrm{CO}_{2}$ quantity difference at $1{ }^{\circ} \mathrm{C}$ interval does not surpass $6 \mathrm{ppm}$ at the end of fermentation time. The same phenomenon takes place at other temperature intervals. From $34{ }^{\circ} \mathrm{C}$ to $35^{\circ} \mathrm{C}$, the $\mathrm{CO}_{2}$ difference is $7 \mathrm{ppm}$. For the next three temperature values, the $\mathrm{CO}_{2}$ release curves become linear in the second part of the fermentation process. At $36{ }^{\circ} \mathrm{C}$, the $\mathrm{CO}_{2}$ value registered at the end of fermentation was $292 \mathrm{ppm}$, at $37{ }^{\circ} \mathrm{C}$, was $307 \mathrm{ppm}$ and at $38{ }^{\circ} \mathrm{C}$ the $\mathrm{CO}_{2}$ value was $315 \mathrm{ppm}$. It can also be observed the difference between the $\mathrm{CO}_{2}$ values registered at $33{ }^{\circ} \mathrm{C}$ and $36{ }^{\circ} \mathrm{C}$ which is 63 ppm, thus obtaining a clear difference between these two fermentation processes. At $39^{\circ} \mathrm{C}$, the final value of $\mathrm{CO}_{2}$ was $351 \mathrm{ppm}$, with $36 \mathrm{ppm}$ more than the final value of $\mathrm{CO}_{2}$ registered at $38{ }^{\circ} \mathrm{C}$ which means that after $37{ }^{\circ} \mathrm{C}$ de development curve does not have a linear pattern. 


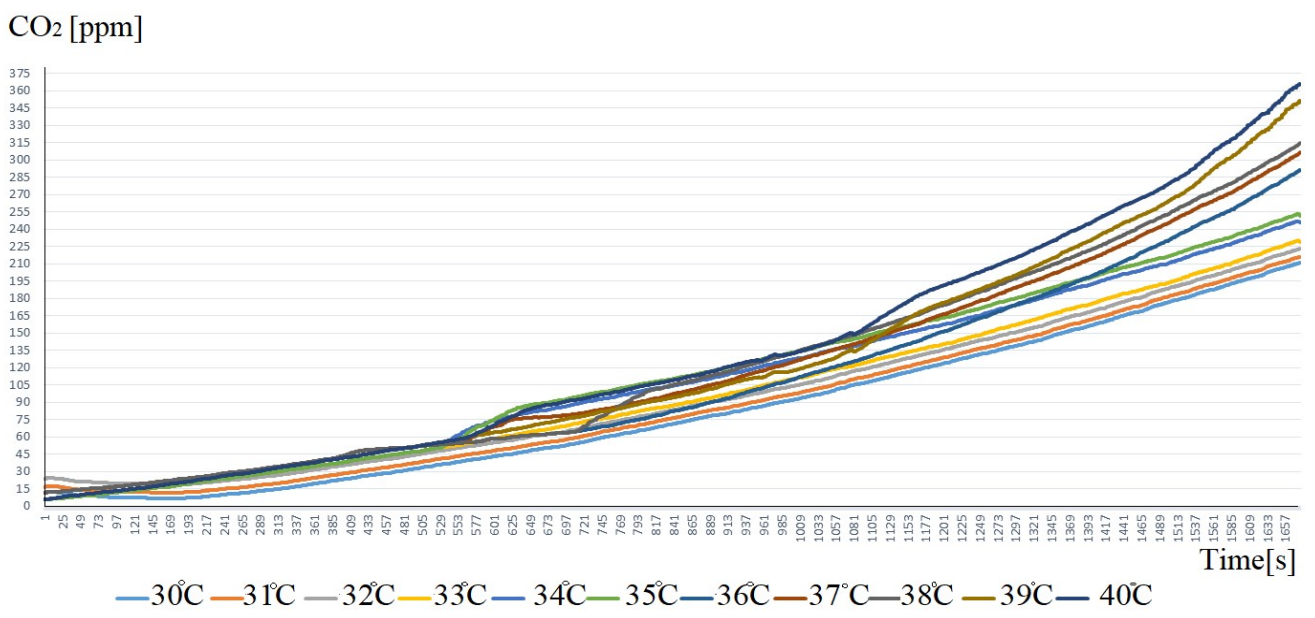

Fig. 2. $\mathrm{CO}_{2}$ values registered during one dough piece fermentation at 11 different temperatures

In figure 3 are presented the differences between the final $\mathrm{CO}_{2}$ values registered during these 11 measurements.

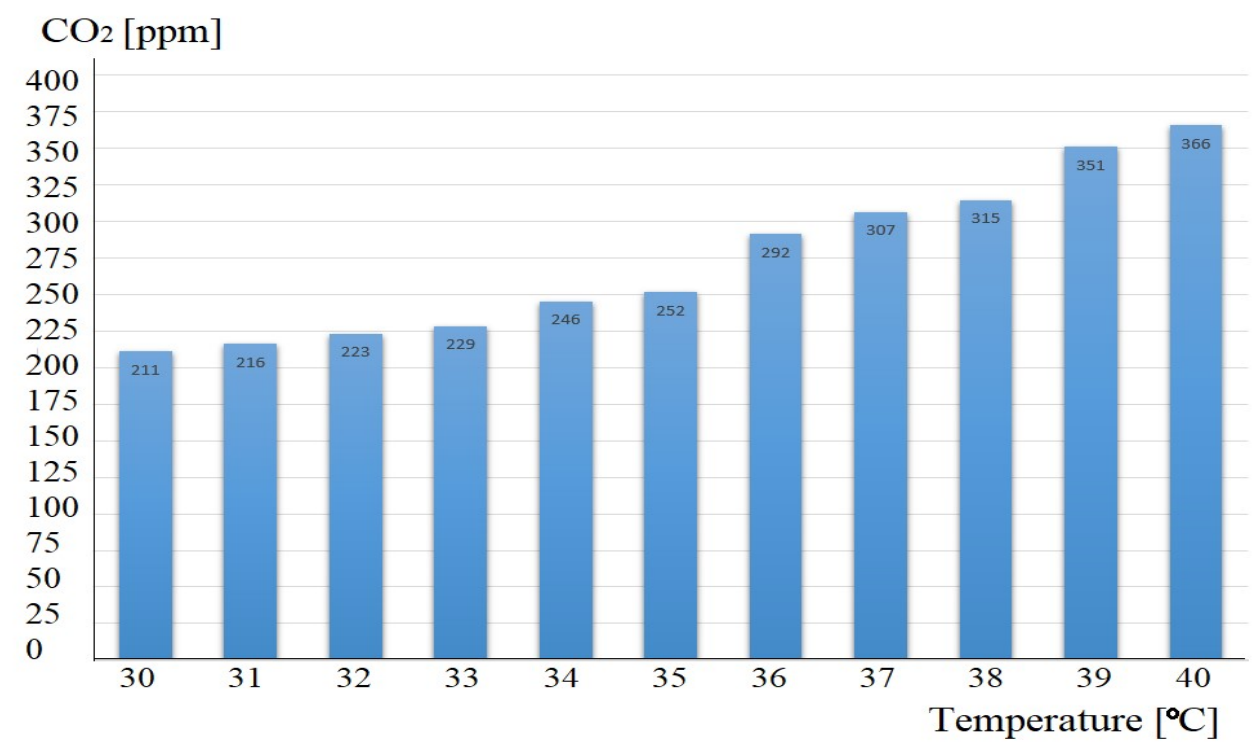

Fig. 3. The $\mathrm{CO}_{2}$ values registered at the end of fermentation time for individual dough pieces at temperatures between $30{ }^{\circ} \mathrm{C}$ and $40{ }^{\circ} \mathrm{C}$

Taking into consideration the results obtained in the first part of the paper, it was established that the relevant dough fermentation temperatures are at $30{ }^{\circ} \mathrm{C}, 33{ }^{\circ} \mathrm{C}, 36{ }^{\circ} \mathrm{C}$, and $39^{\circ} \mathrm{C}$. In figure 4 are presented the comparative values between the $\mathrm{CO}_{2}$ quantity released during the fermentation process at these temperatures and the obtained volume of bread pieces. 
Taking into consideration the percentage difference between the second and the first values it can be observed that there is a correspondence between the $\mathrm{CO}_{2}$ values and the obtained volume. Therefore, at $33{ }^{\circ} \mathrm{C}$, in comparison with $30{ }^{\circ} \mathrm{C}$, the concentration of released $\mathrm{CO}_{2}$ and the volume of bread increase with $7.9 \%$ and $7.5 \%$ respectively. At $36^{\circ} \mathrm{C}$, the obtained results show an increase of $17.3 \%$ for the volume of bread and $21.6 \%$ for the concentration of $\mathrm{CO}_{2}$. From $36^{\circ} \mathrm{C}$ to $39^{\circ} \mathrm{C}$, the increase in volume reduces to $14 \%$ and the $\mathrm{CO}_{2}$ release to $16.8 \%$.

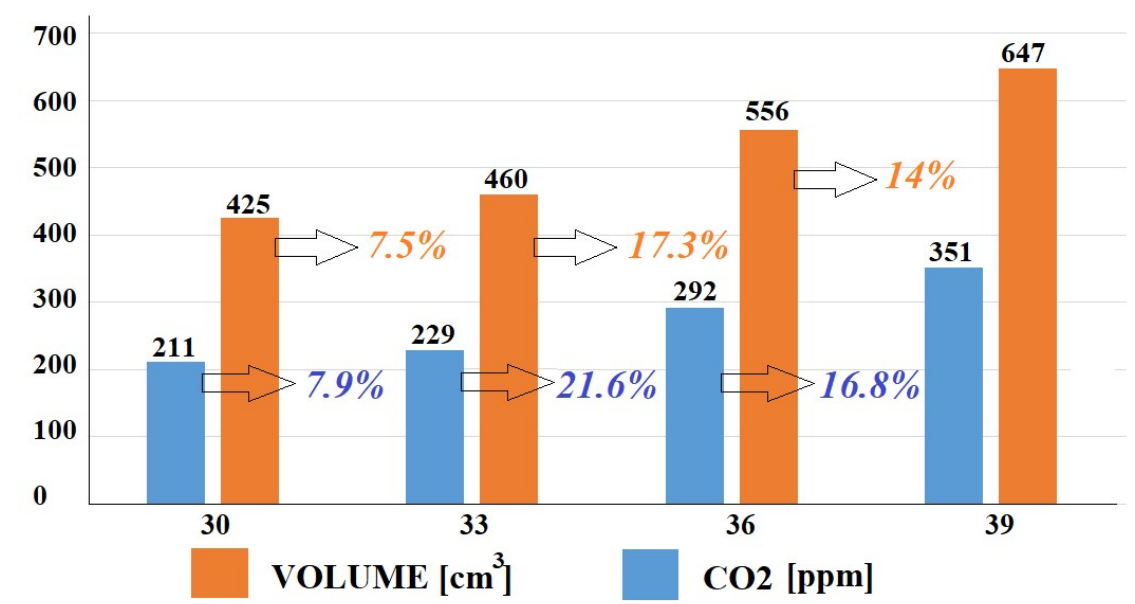

Fig. 4. The comparative percentage values between the volume of bread and the $\mathrm{CO}_{2}$ quantity registered at 4 different temperatures

In the second part of the paper, measurements were performed for the quantity of $\mathrm{CO}_{2}$ released during the proving process of 9 dough pieces of $360 \mathrm{~g}$ each. The obtained results are presented in figure 5 .

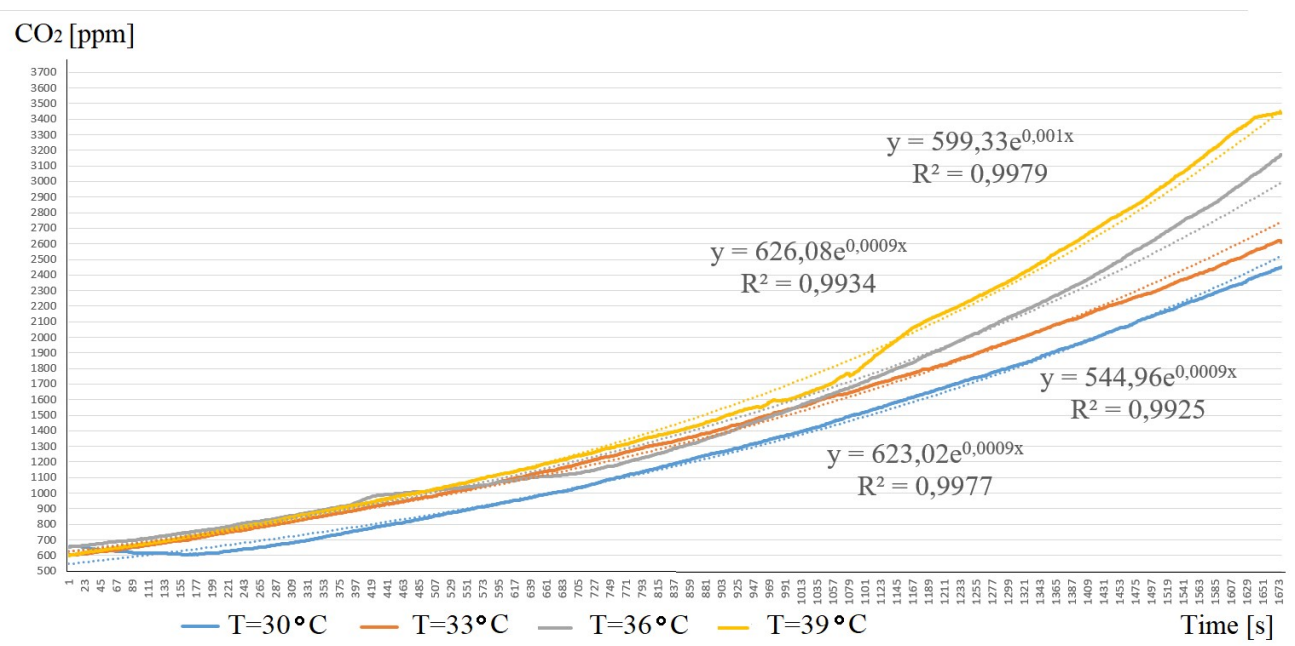

Fig. 5. $\mathrm{CO}_{2}$ release curves for 9 dough pieces and the correlation coefficient $\mathrm{R}^{2}$ 
From the analysis of $\mathrm{CO}_{2}$ curves obtained during the process fermentation at temperatures between $30{ }^{\circ} \mathrm{C}$ and $39{ }^{\circ} \mathrm{C}$ at $3{ }^{\circ} \mathrm{C}$ intervals, it can be observed that the first 2 $\mathrm{CO}_{2}$ curves register a constant development until the end of fermentation and the other 2 curves, at $36{ }^{\circ} \mathrm{C}$ and $39{ }^{\circ} \mathrm{C}$ register a rapid accumulation of $\mathrm{CO}_{2}$ in the second part of the fermentation process. Thus, at the end of the fermentation time, the values obtained for the $\mathrm{CO}_{2}$ quantity were: $1900 \mathrm{ppm}$ at $30{ }^{\circ} \mathrm{C}, 2057 \mathrm{ppm}$ at $33{ }^{\circ} \mathrm{C}, 2624 \mathrm{ppm}$ at $36{ }^{\circ} \mathrm{C}$ and 2892 ppm at $39^{\circ} \mathrm{C}$.

The $\mathrm{CO}_{2}$ release curves during the fermentation process of wheat dough are defined by the exponential relation: $y=b \cdot e^{a \cdot x}$. The correlation coefficients $R^{2}$ obtained for all the four experiments had over 0.99 . This high values satisfy the exigence level required for these kind of measurements which have as main purpose the determination of the level of fermentation of dough in correspondence with the proving temperature and released $\mathrm{CO}_{2}$ quantity during a specific time.

After each experiment, the dimensions of dough pieces were measured. The obtained mean values are presented in table 2 .

Table 2. Dough pieces dimensions after final fermentation

\begin{tabular}{|l|l|l|l|l|}
\hline Dimension & \multicolumn{4}{|c|}{$\mathrm{CO}_{2} /$ temperature } \\
\hline & $1900 \mathrm{ppm} / 30^{\circ} \mathrm{C}$ & $2057 \mathrm{ppm} / 33^{\circ} \mathrm{C}$ & $2624 \mathrm{ppm} / 36^{\circ} \mathrm{C}$ & $2892 \mathrm{ppm} / 39^{\circ} \mathrm{C}$ \\
\hline $\mathrm{L}(\mathrm{cm})$ & 29 & 29 & 29 & 30 \\
\hline $1(\mathrm{~cm})$ & 9.5 & 10 & 11 & 12.4 \\
\hline $\mathrm{H}(\mathrm{cm})$ & 6 & 6.5 & 7.5 & 6 \\
\hline
\end{tabular}

\section{Conclusions}

In this paper it was analysed the influence of proving temperature on the final fermentation level of wheat dough based on the concentration of released carbon dioxide in the proving cabinet.

In the first part of the paper, 11 fermentation test were performed at temperatures ranging between $30{ }^{\circ} \mathrm{C}$ and $40{ }^{\circ} \mathrm{C}$, at $1{ }^{\circ} \mathrm{C}$ interval in order to determine the influence of 1 ${ }^{\circ} \mathrm{C}$ on the fermentation intensity. Based on the $\mathrm{CO}_{2}$ release curves it was observed that temperature intervals are created, at $3{ }^{\circ} \mathrm{C}$ approximately, in which the fermentation intensity level registers little differences in the $\mathrm{CO}_{2}$ values (not more than $6 \mathrm{ppm}$ ). The $\mathrm{CO}_{2}$ value difference between $33{ }^{\circ} \mathrm{C}$ and $36{ }^{\circ} \mathrm{C}$ was $63 \mathrm{ppm}$ and after $37{ }^{\circ} \mathrm{C}$, the $\mathrm{CO}_{2}$ concentration increase up to $40 \mathrm{ppm}$ at $1{ }^{\circ} \mathrm{C}$ intervals. From the analysis of the characteristic curves presented in figure 2 , it can be observed that the quantity of $\mathrm{CO}_{2}$ released during the fermentation process at temperatures between $37-39{ }^{\circ} \mathrm{C}$ increases in a more accelerated rate in the second part of the fermentation process due to the temperature increase in the dough piece.

The increase in $\mathrm{CO}_{2}$ concentration related to higher temperatures is very much influenced by the physio-chemical characteristics of the flour used in preparing the dough, the recipe, more specifically the consistency of dough and the quantity of yeast. Of much importance is also the temperature of dough at the fermentation starting point. Therefore, using a softer dough with a high quantity of yeast will result in a higher concentration of $\mathrm{CO}_{2}$ during the fermentation process. 
Although the highest volume of bread was obtained after dough was fermented at 39 ${ }^{\circ} \mathrm{C}$, it can be observed in table 2 that the dimensions of the dough pieces do not correspond with the desired quality level. Considering the measured dough dimensions, the best development of dough and of $\mathrm{CO}_{2}$ release was registered around the $36{ }^{\circ} \mathrm{C}$ temperature point.

From the analysis of the results obtained in the second part of the paper, the fermentation process of dough is exponential. The accuracy of the performed measurements was validated using the correlation coefficients $\left(\mathrm{R}^{2}\right)$, whose values registered for all 4 experiments were higher than 0.99 .

The quantity of released $\mathrm{CO}_{2}$ during the fermentation process was correlated with the measured dimensions of dough pieces after each experiment.

Taking into consideration the value intervals registered in STAS regarding the quality level of white bread of $300 \mathrm{~g}$, it was established that the best product with the most correct dimensions regarding the report $\mathrm{L} / \mathrm{W} / \mathrm{h}$ was the one fermented around the $36{ }^{\circ} \mathrm{C}$ temperature, with a $\mathrm{CO}_{2}$ release value in an hour of $2624 \mathrm{ppm}$, in a closed proving cabinet of $0.36 \mathrm{~m}^{3}$.

Further research regard the analysis of $\mathrm{CO}_{2}$ quantity in an industrial prover with continuous functioning during the fermentation process and the possibility of working regime control using the $\mathrm{CO}_{2}$ released quantity.

This work has been funded by the European Social Fund from the Sectoral Operational Programme Human Capital 2014-2020, through the Financial Agreement with the title "Scholarships for entrepreneurial education among doctoral students and postdoctoral researchers (Be Antreprenor!)", Contract no. 51680/09.07.2019 - SMIS code: 124539.

\section{References}

1. A. Istudor et al, Final bread dough fermentation - requirements, conditions, equipment. A short review, INMA-TEH, (2017), pp. 519-526;

2. P. Shah, G. Campbell, S. McKee, \& C. Rielly, Proving of bread dough: modelling the growth of individual bubbles. Transactions of the Institution of Chemical Engineers, Part C, 76, (1998), pp. 73-79;

3. G. Voicu, Procese şi utilaje pentru panificaţie, E. Bren, Bucureşti, (1999);

4. R.C. Hoseney, Principles of cereal science and technology, 2nd ed., Minnesota, USA: AACC Inc., (1998);

5. M.G Scanlon, M.C. Zghal, Bread properties and crumb structure, FRI, 34, (2001), pp. 841-864;

6. A. Istudor, G. Voicu et. al, Evaluation of wheat dough fermentation process using a reactor and mathematical modelling, SGEM, 18, (2018), pp. 161-168;

7. I. Svec, M. Hruskova, Wheat flour fermentation study, CJFS, 22, 2004, pp. 17-23;

8. A. Ktenioudaki, F. Butler, E. Gallagher, Dough characteristics of Irish wheat varieties II. Aeration profile and baking quality. LWT-FST, 44, 2011, pp. 602610 ;

9. J. Šavel, P. Košin, A. Brož, Calculation of pressure growth during fermentation in a closed container, Kvasny prum 9, 60, (2014), pp 233-238;

10. G. E. Rattin, J. M. Faubion, C.E. Walker, A.L. Mense, Measuring yeast $\mathrm{CO} 2$ production with the Risograph, CFW, 54, 6, (2009), pp: 261-265;

11. *** STAS 91/1983, available at http://www.rompan.ro/analize-de-laborator/, accessed in 22.03.2020. 